\title{
SOME PHYSICO-CHEMICAL CHARACTERS OF GROUNDWATER IN SOME (Selected) WATER SUPPLY WELLS IN THE JAFFNA PENINSULA.
}

\author{
T. NANTHINI, T. MIKUNTHAN* and R.VIJAYARATNAM \\ Department of Agriculture Engineering, Faculty of Agriculture, University of Jaffna.
}

(Received: 16 March 2000 ; accepted: 06 November 2000)

\begin{abstract}
The study focussed on the criteria used in assessing the quality of ground water. Among physical properties, turbidity, colour, odour and taste and among chemical properties; chloride, iron and sulphate concentration, total alkalinity, total dissolved solids, electrical conductivity and $\mathrm{pH}$ were determined for seven water supply wells. These values were compared with WHO standards and Sri Lankan standard values. Water supply wells at Velanai and Chunnakam did not have quality problems and can be used continuously for human consumption. Extraction of water from water supply wells at Araly South, Vaddukoddai and Watharawatta could be extended but continuous monitoring of chemical characters is essential. Kayts and Karaveddy wells could not be used for drinking because some chemical and physical characters of these wells did not meet WHO and Sri Lankan standards.
\end{abstract}

Keywords: Groundwater, Jaffna peninsula, salinity, shallow wells, Sri Lanka, water . supply wells.

\section{INTRODUCTION}

Groundwater has been an important natural resource of the Jaffna peninsula throughout the ages. The population of the Jaffna peninsula depends entirely on the limited groundwater resources to meet all of their water requirements. In recent times concern has been expressed about the increase in salinity and poor quality of well water due to sea water intrusion into the fresh water lens, ${ }^{1.2}$ nitrate pollution through continuous and liberal use of organic manure and inorganic fertilizers, ${ }^{3}$ over extraction or rapid rate of extraction using mechanical and electrical pumps, ${ }^{45}$ intensive agricultural practices, ${ }^{4}$ and improper planning of soakage pits and latrines. ${ }^{5}$ Among the 65 tested wells about $65 \%$ of wells in Jaffna peninsula had highly saline water whereas in the islands more than $80 \%$ of the wells were very high in salinity. ${ }^{4}$ A water supply system with good quality water is essential for these identified areas at least to satisfy their requirement specially for domestic drinking purposes. Water quality, being measured by a combination of various parameters, is important because unacceptable levels of any constituent can render a water source unusable. Certain constituents can make water unwholesome and even hazardous for human consumption. Hence a monitoring program for periodic assessment of water quality of water supply schemes is essential to protect public health and to ensure continued supplies of safe drinking water. In the Jaffna Peninsula only a few wells are functioning for pumping water due to the intermittent displacement of people by changing military situations. In this study, only water 
supply wells maintained by the National Water Supply and Drainage Board of Jaffna Peninsula functioning during the study period were selected. The Municipality of Jaffna maintains the two other functioning water supply wells, namely Kondavil and Thirunelvely, which are used to pump water by recharge from adjoining wells. These two wells are used to pump water alternately with one- hour duration and no reports are available to indicate the development of salinity in these two areas. Hence these wells were excluded in this study. The water supply wells in this study were particularly selected as no such studies were made previously to assess the quality of drinking water periodically in this region.

\section{METHODS AND MATERIALS}

General features of selected water supply wells: Vaddukkoddai, Chunnakam, Araly South, Velani, Kayts, Watharawatta and Karaveddy water supply wells of the National Water Supply and Drainage Board, Jaffna were selected for this study (Figure 1). Table 1 indicates the number of families which receive water from the respective water supply wells, length of the pipeline and number of pipe outlets. The wells under these schemes are shallow and measure 10 to $26 \mathrm{~m}$ in depth and 6 to $14 \mathrm{~m}$ in diameter.

Table 1 : Distribution of water supply schemes

\begin{tabular}{lccc}
\hline Location of wells & $\begin{array}{c}\text { Number of families } \\
\text { supplied }\end{array}$ & $\begin{array}{c}\text { Length of the } \\
\text { Pipe line }(\mathrm{km})\end{array}$ & $\begin{array}{c}\text { Number of pipe } \\
\text { outlets }\end{array}$ \\
\hline Vaddukkodai & 5000 & 19.71 & 27 \\
Chunnakam & 5000 & 27.65 & 30 \\
Araly South & 8000 & 58.27 & 27 \\
Velanai & 4700 & 88.86 & 26 \\
Kayts & 8000 & 88.87 & 60 \\
Watharawatta & 25000 & 71.5 & 11 cistern tank \\
Karaveddy & 14000 & 177.89 & 97 \\
\hline
\end{tabular}

Source: National Water Supply and Drainage Board, Jaffna

Design of sampler: The sampler (Figure 2) was made of an iron cylinder of one litre capacity. The upper end of the cylinder was sealed but contains three holes through which the water can enter into the cylinder. A movable piston was set up inside the cylinder and connected with the upper part of the sampler. Two long running threads were tied each on the middle of the cylinder as well as to the piston. The thread fixed to the piston was used to bring down the sampler to a desired depth. Once the sampler reached to a desired depth the thread fixed to the piston was relaxed by 
tightening the other thread, which was fixed to the cylinder. After a few minutes again the thread fixed to the piston was tightened, while relaxing the other, and the sampler was taken out from the well.

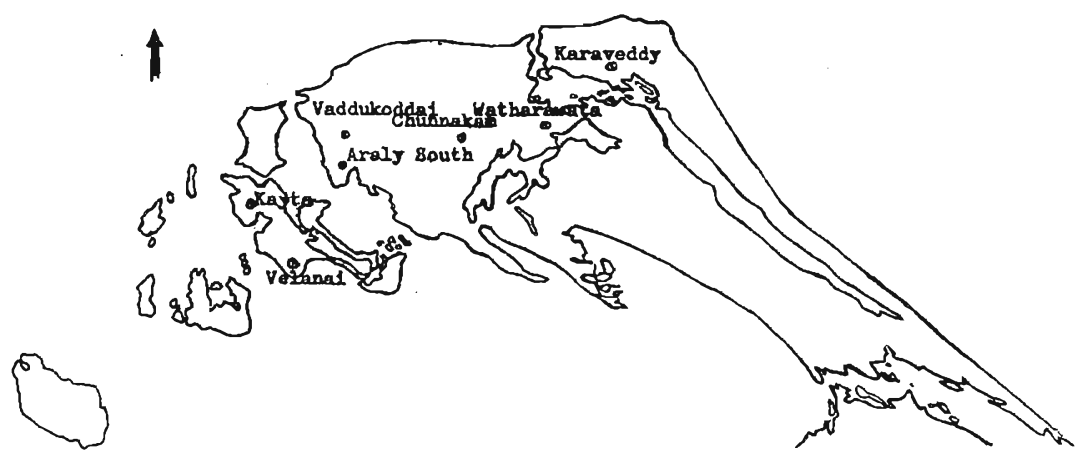

SCALE : UNCONTROLLED REDUCTION

Figure 1: Location of the water supply wells in Jaffna peninsula

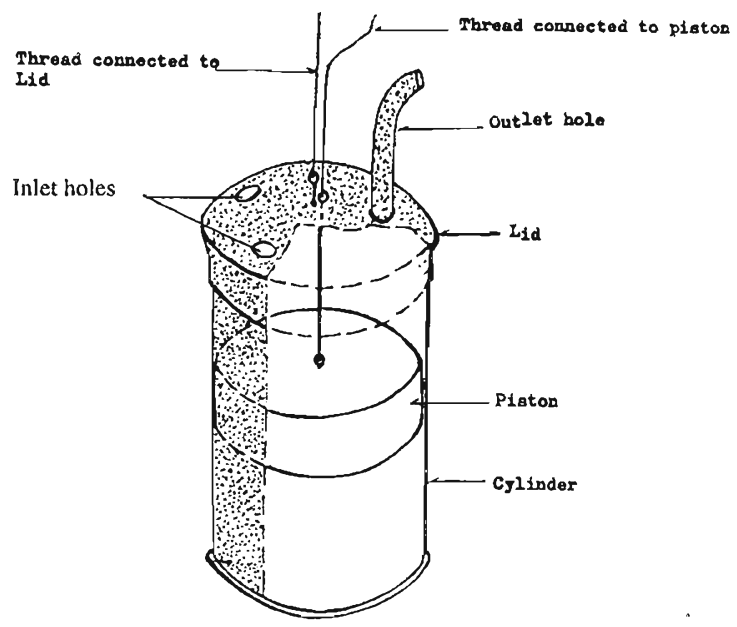

Figure 2: Diagram of sampler

Collection of water sample: Samples of water were drawn from seven water supply shallow wells at three different levels: surface, middle and bottom of the water column in a well except for the measurement of concentration of iron and sulphate for which only one sample was collected. The water samples were transferred to one litre pre- cleaned plastic bottles and these bottles were rinsed several times with respective well water before collection. Bottles were labelled and tightly closed and brought to the laboratory of National Water Supply and Drainage Board, Jaffna. 
This procedure was carried out for the period September '97 to July '99 at monthly intervals.

Table 2: Selected chemical properties and method of analysis

\begin{tabular}{|c|c|c|c|}
\hline $\begin{array}{l}\text { Chemical } \\
\text { characters }\end{array}$ & Method of analysis & $\begin{array}{c}\text { Standard } \\
\text { parameters }\end{array}$ & Values \\
\hline $\begin{array}{l}\text { Chloride } \\
\text { content }\end{array}$ & Mohr's titration method & $\begin{array}{c}\text { WHO } \\
\text { SLS MAX DES } \\
\text { SLS MAX PER }\end{array}$ & $\begin{array}{l}250 \mathrm{mg} / \mathrm{l} \\
100 \mathrm{mg} / \mathrm{l} \\
200 \mathrm{mg} / 1\end{array}$ \\
\hline Total Alkalinity & $\begin{array}{l}\text { Titration with standard } \\
\text { solution of Hydrochloric } \\
\text { acid }\end{array}$ & $\begin{array}{l}\text { SLS MAX DES } \\
\text { SLS MAX PER }\end{array}$ & $\begin{array}{l}200 \mathrm{mg} / 1 \\
400 \mathrm{mg} / 1\end{array}$ \\
\hline $\begin{array}{l}\text { Total dissolved } \\
\text { solids }\end{array}$ & $\begin{array}{c}1.56^{*} \times \text { Electrical } \\
\text { conductivity }(\mathrm{mg} / \mathrm{l})\end{array}$ & WHO & $1500 \mathrm{mg} / 1$ \\
\hline Iron & $\begin{array}{l}\text { Spectrophotometer } \\
\text { (Ferrover method) }\end{array}$ & $\begin{array}{l}\text { WHO } \\
\text { SLS MAX DES } \\
\text { SLS MAX PER }\end{array}$ & $\begin{array}{l}0.3 \mathrm{mg} / 1 \\
0.3 \mathrm{mg} / 1 \\
1.0 \mathrm{mg} / \mathrm{l}\end{array}$ \\
\hline Sulphate & $\begin{array}{c}\text { Spectrophotometer } \\
\text { (Sulfa ver } 4 \text { regent method) }\end{array}$ & $\begin{array}{l}\text { WHO } \\
\text { SLS MAX DES } \\
\text { SLS MAX PER }\end{array}$ & $\begin{array}{l}400 \mathrm{mg} / \mathrm{l} \\
200 \mathrm{mg} / 1 \\
400 \mathrm{mg} / 1\end{array}$ \\
\hline $\mathrm{pH}$ & $\begin{array}{c}\text { Cyberscan series } \mathrm{pH} \\
\text { meter }\end{array}$ & $\begin{array}{c}\text { WHO MIN } \\
\text { WHO MAX } \\
\text { SLS DES MAX } \\
\text { SLS DES MIN } \\
\text { SLS PER MAX } \\
\text { SLS PER MIN }\end{array}$ & $\begin{array}{l}6.6 \\
8.0 \\
7.0 \\
8.5 \\
6.5 \\
9.0\end{array}$ \\
\hline $\begin{array}{l}\text { Electrical } \\
\text { conductivity }\end{array}$ & $\begin{array}{c}\text { Cyberscan conductivity } \\
\text { portable meter }\end{array}$ & $\begin{array}{l}\text { SLS MAX DES } \\
\text { SLS MAX PER }\end{array}$ & $\begin{array}{l}1500 \mu \mathrm{s} / \mathrm{cm} \\
3500 \mu \mathrm{s} / \mathrm{cm}\end{array}$ \\
\hline
\end{tabular}

“DES" = Desirable

"PER" = Permissible 
Analytical Techniques: Characters such as turbidity (Formagin turbidity unit, FTU) and colour (Platinum cobalt unit, pt Co) were measured using a spectrophotometer model DR/2000 and the taste and odour were sensorily evaluated at the well site. The summary of selected chemical characters, method of analysis, standard drinking water quality parameters of $\mathrm{WHO}^{6}$ and Sri Lankan standard ${ }^{7}$ values, which were used for comparison, are given in Table 2 . All chemical characteristic values were statistically analysed by hypothesis test within the three levels of monthly data.

\section{RESULTS AND DISCUSSION}

The results showed no significant variation among monthly values of parameters for water samples taken at the three levels. Hence the mean values of these were taken to represent the respective monthly values.

\section{Physical characters}

Out of 7 tested water supply wells, maximum turbidity and colour values were observed in Karaveddy water supply well (Table 3) while in other water supply wells, these values were observed as less than 1 and in some months even zero. The condition of taste and odour were found as unobjectionable except Karaveddy and Kayts water supply wells in which the water tasted slightly salty.

Table 3: Monthly variation of turbidity and colour of Karaveddy water supply well during a calendar year

\begin{tabular}{|c|c|c|c|c|c|c|c|c|c|c|c|c|}
\hline Character & Jan. & Feb. & Mar. & Apr. & May & Jane & July & Aug. & Sep. & Oct. & Nov. & $\overline{\mathrm{Dec}}$ \\
\hline $\begin{array}{l}\text { Turbidity } \\
\text { (FTU) }\end{array}$ & 18 & 20 & 28 & 12 & 19 & 6 & 4.5 & 1.3 & 1.8 & 3.5 & 5 & 6 \\
\hline $\begin{array}{l}\text { Colour } \\
\text { (pt Co) }\end{array}$ & 18 & 24 & 36 & 14 & 28 & 16 & 18 & 14 & 14 & 16 & 19 & 21 \\
\hline
\end{tabular}

Chemical characters: The variations of chemical characters with respect to time in a calendar year for seven selected water supply wells are shown in Figures 3 to 8 , the $\mathrm{pH}$ variation is shown in Table 4.

Water from the supply well at Karaveddy, which is situated within the mainland (Figure 1), showed deviation from standard levels in chloride (Figure 3), iron concentration (Figure 7), total alkalinity (Figure 5), taste, odour, colour and turbidity (Table 3 ). Highest chloride and iron concentrations were observed in this water supply well and also during some months such values were twice the safety level specified by WHO (Figures $3 \& 7$ ). This would be due to over exploitation of 
water from the well. The possible valid reasons for this situation were increased demand of the largest number of families in this area (Table 1) and leaching of ion from surrounding fields due to indiscriminate use of agrochemicals and fertilizers during Maha for paddy cultivation and during Yala for other field crops, specially onion. This water supply well is situated within the periphery of a pond constructed in the centre of low-lying areas of the paddy field. Additionally the pond is recharged by water received from the surrounding areas during rainy season. Further, a road running along the periphery of the fields was repaired every year with a bulk quantity of salty mud. During rainy season this salty mud was washed off and finally deposited in the paddy fields. During dry season, when the water is confined within the pond the salty mud accumulates in greater concentration. This undesirable practice is responsible for a part of this salinity problem. The characteristics of the sandy aquifer might be the reason for the high concentration of iron in ground water and normally this problem exists in hard rock terrains as well as in alluvial aquifers. This problem is also reflected in taste, odour, colour and turbidity.

\section{Table.4 : Monthly fluctuation of $\mathrm{pH}$ of water for seven selected water supply wells.}

\begin{tabular}{lcccccccccccc}
\hline Location of well & Jan. & Feb. & Mar. & Apr. & May & Jun. & Jul. & Aug. & Sep. & Oct. & Nov. & Dec. \\
\hline Vaddukoddai & 7.28 & 7.40 & 7.78 & 7.29 & 7.8 & 7.39 & 7.35 & 7.43 & 7.39 & 7.53 & 7.30 & 7.55 \\
Chunnakam & 6.81 & 6.62 & 6.64 & 7.26 & 6.73 & 6.98 & 6.78 & 6.54 & 7.08 & 6.87 & 6.98 & 7.35 \\
Araly South & 7.30 & 7.27 & 7.24 & 6.91 & 7.09 & 7.04 & 7.20 & 7.22 & 7.24 & 7.39 & 7.33 & 7.44 \\
Velanai & 7.45 & 7.36 & 7.49 & 7.30 & 7.52 & 7.24 & 6.90 & 7.59 & 7.60 & 7.60 & 7.39 & 7.39 \\
Kayts & 7.40 & 7.58 & 7.40 & 7.26 & 7.28 & 7.26 & 7.10 & 7.37 & 7.14 & 7.77 & 7.32 & 7.47 \\
Watharawatta & 7.06 & 6,78 & 6,95 & 7,57 & 7.03 & 7.19 & 7.22 & 7.66 & 7.56 & 6.99 & 7.00 & 7.41 \\
Karaveddy & 7.09 & 7.14 & 7.05 & 7.41 & 7.58 & 7.16 & 7.09 & 7.02 & 7.14 & 7.03 & 7.35 & 7.25 \\
\hline
\end{tabular}

The water supply well at Kayts had problems in which chloride concentration (Figure 3) and total alkalinity (Figure 5), sulphate (Figure 8) and taste were higher than the standard levels. The reason for the increased chloride concentration would be due to the Island effect. Karaveddy and Kayts water supply wells cannot be used for further pumping of water for drinking as some physical and chemical characters of these wells deviated from the standard levels. Hence, good quality wells of required capacity have to be selected in place of these wells to rectify this problem as well as to substantiate the requirements. The system adopted in the Velanai water supply well, ie: selecting good quality wells close to the main water supply well and interconnecting them to receive all recharged water for the pumping from the main well, would also be a remedy for this problem. 

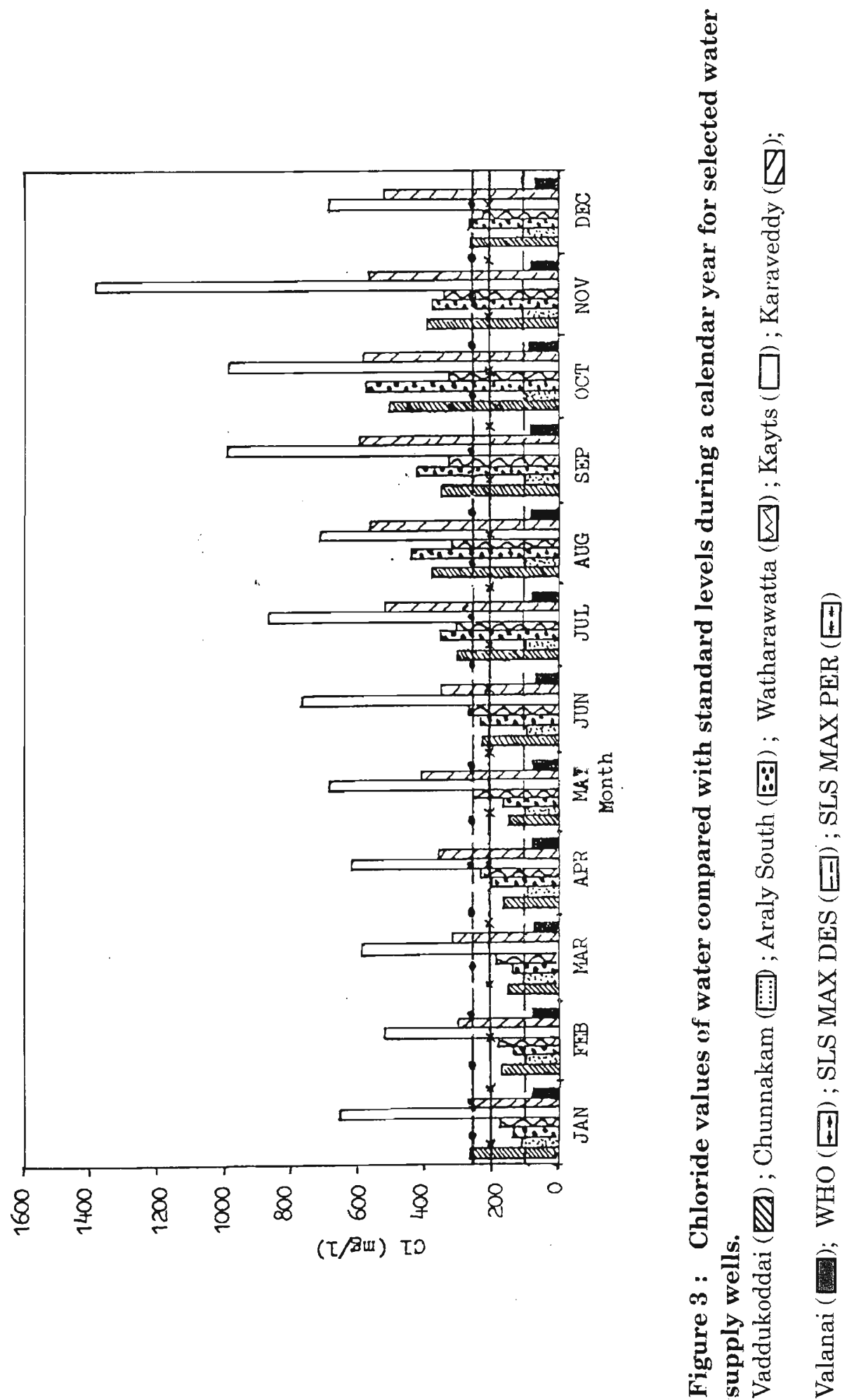

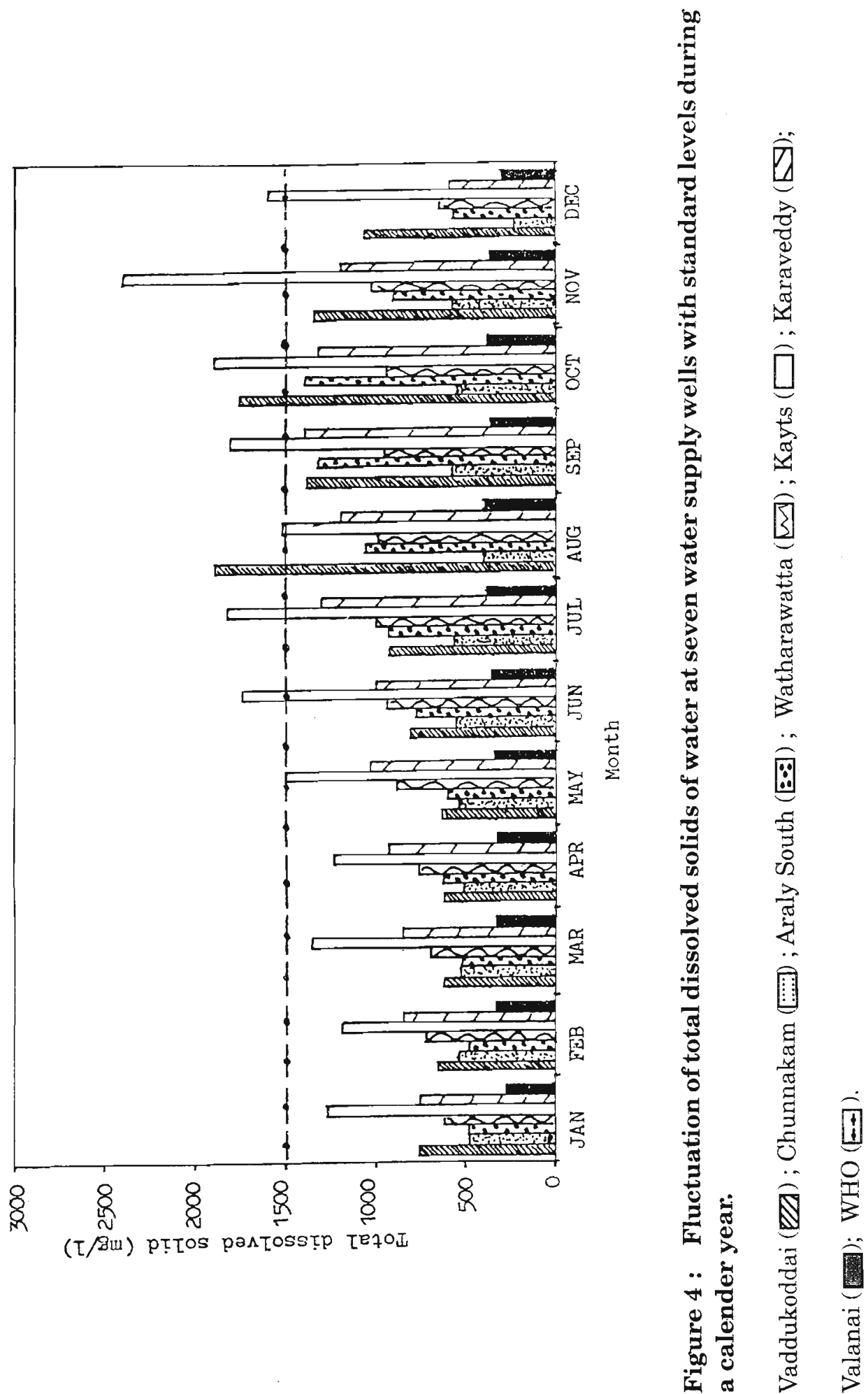


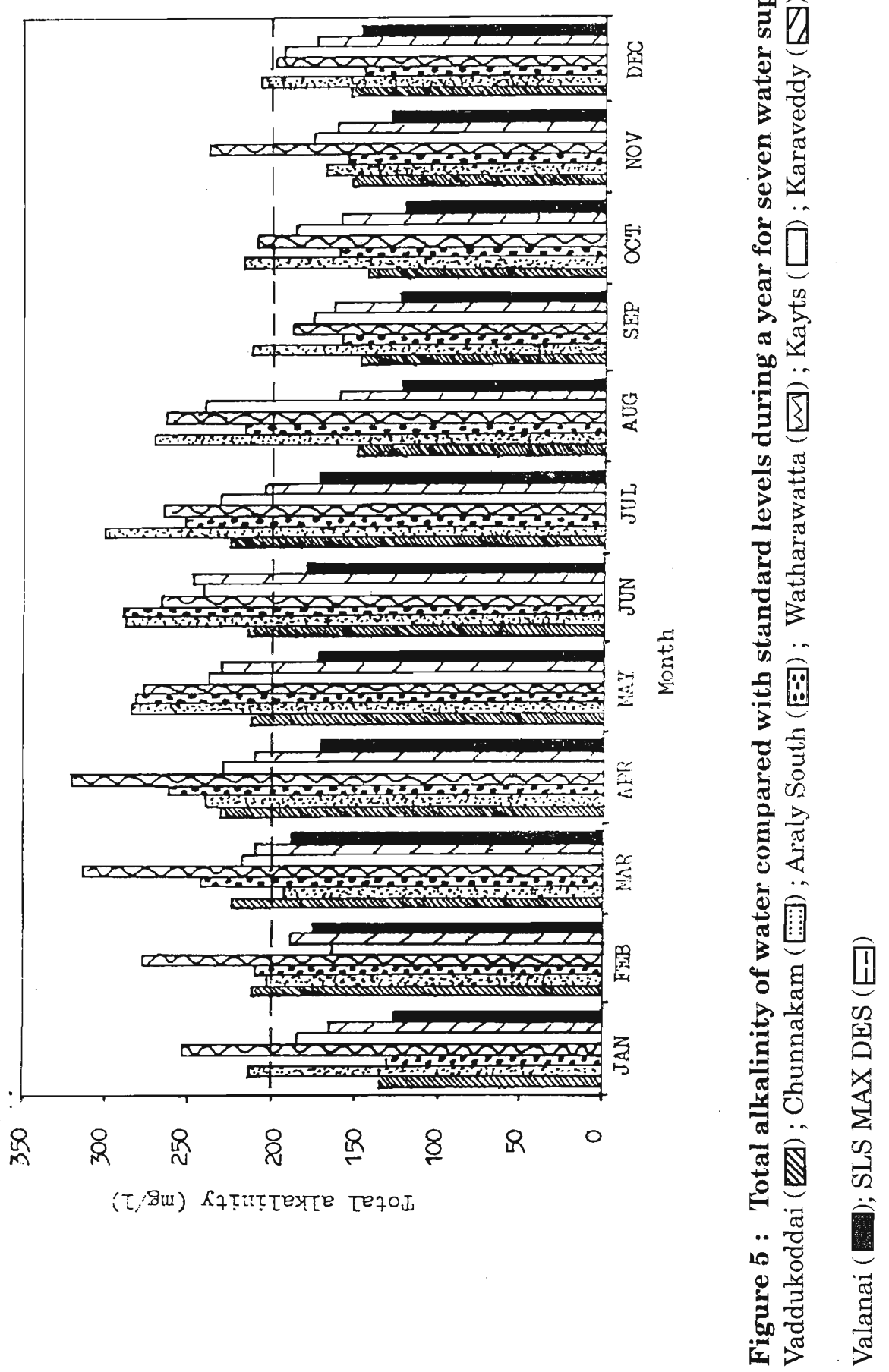



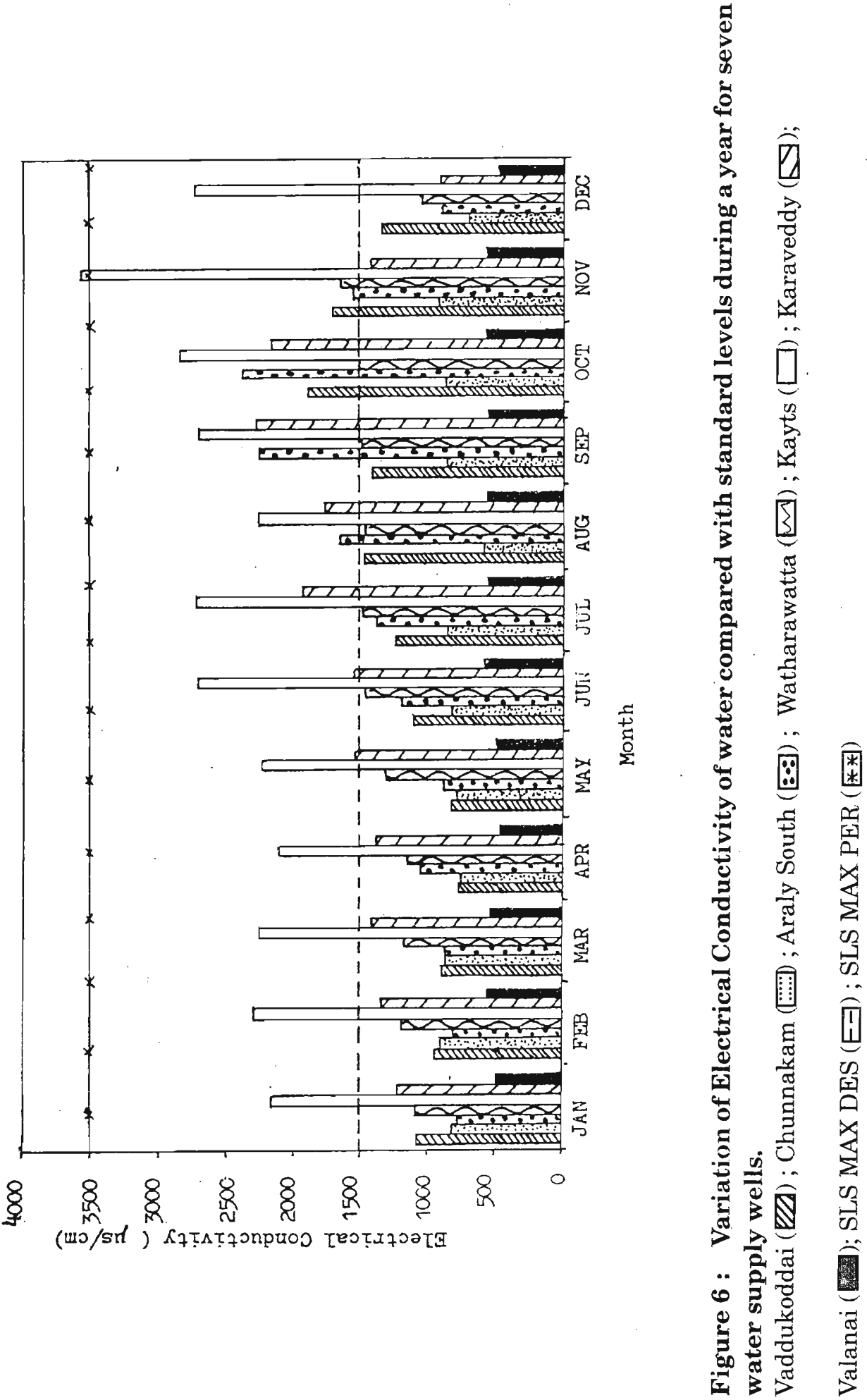


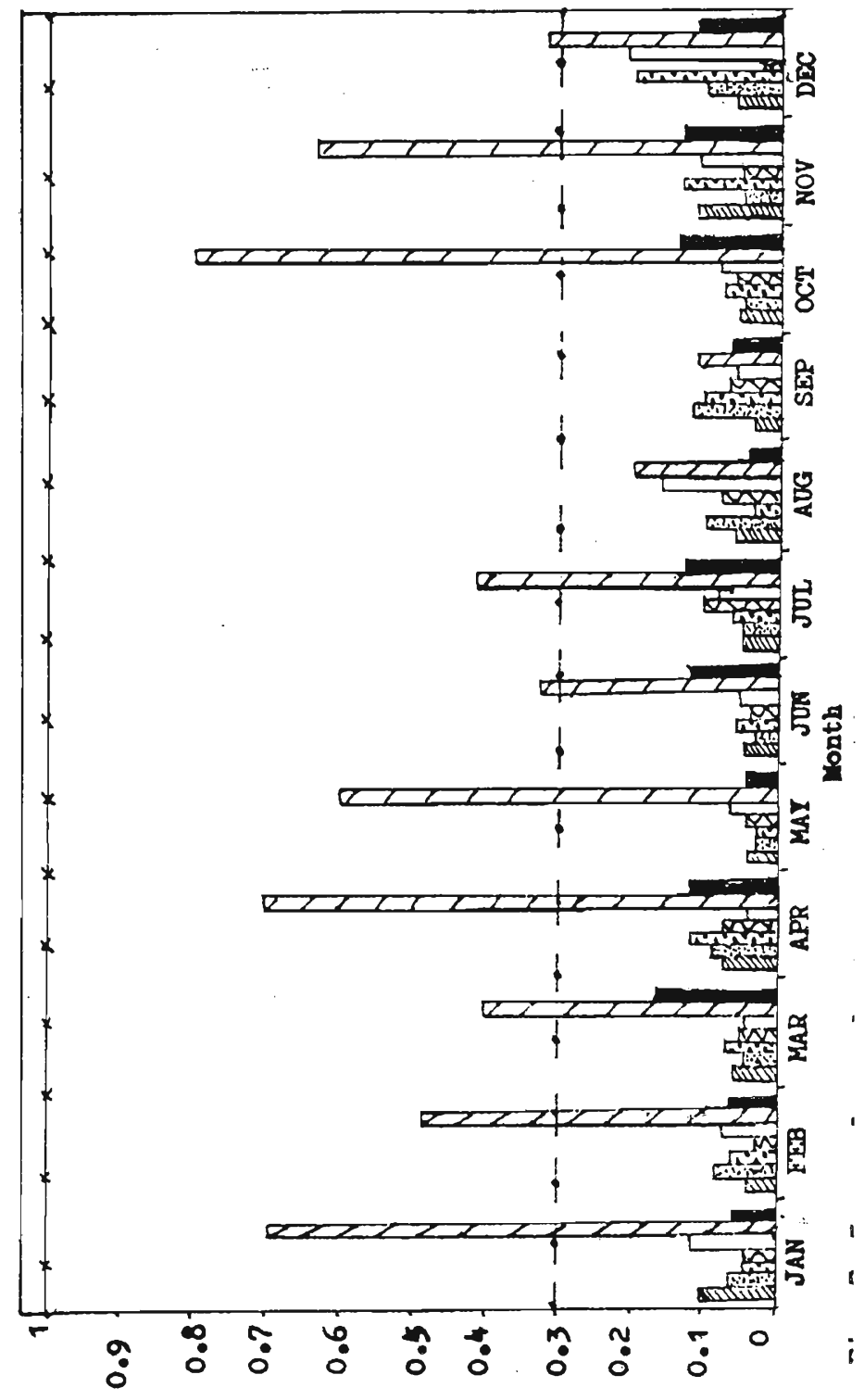

(T/8x) noxI

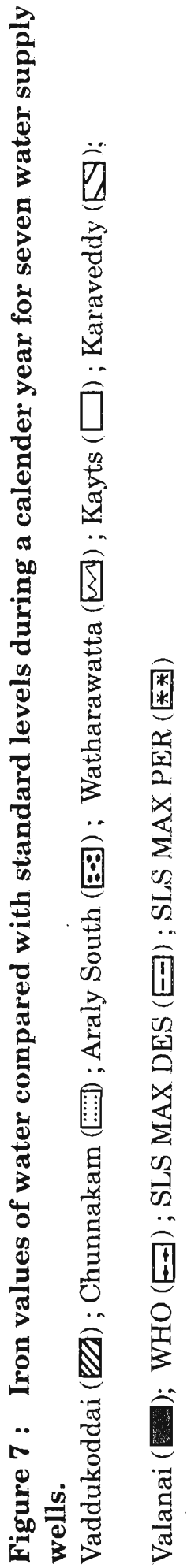



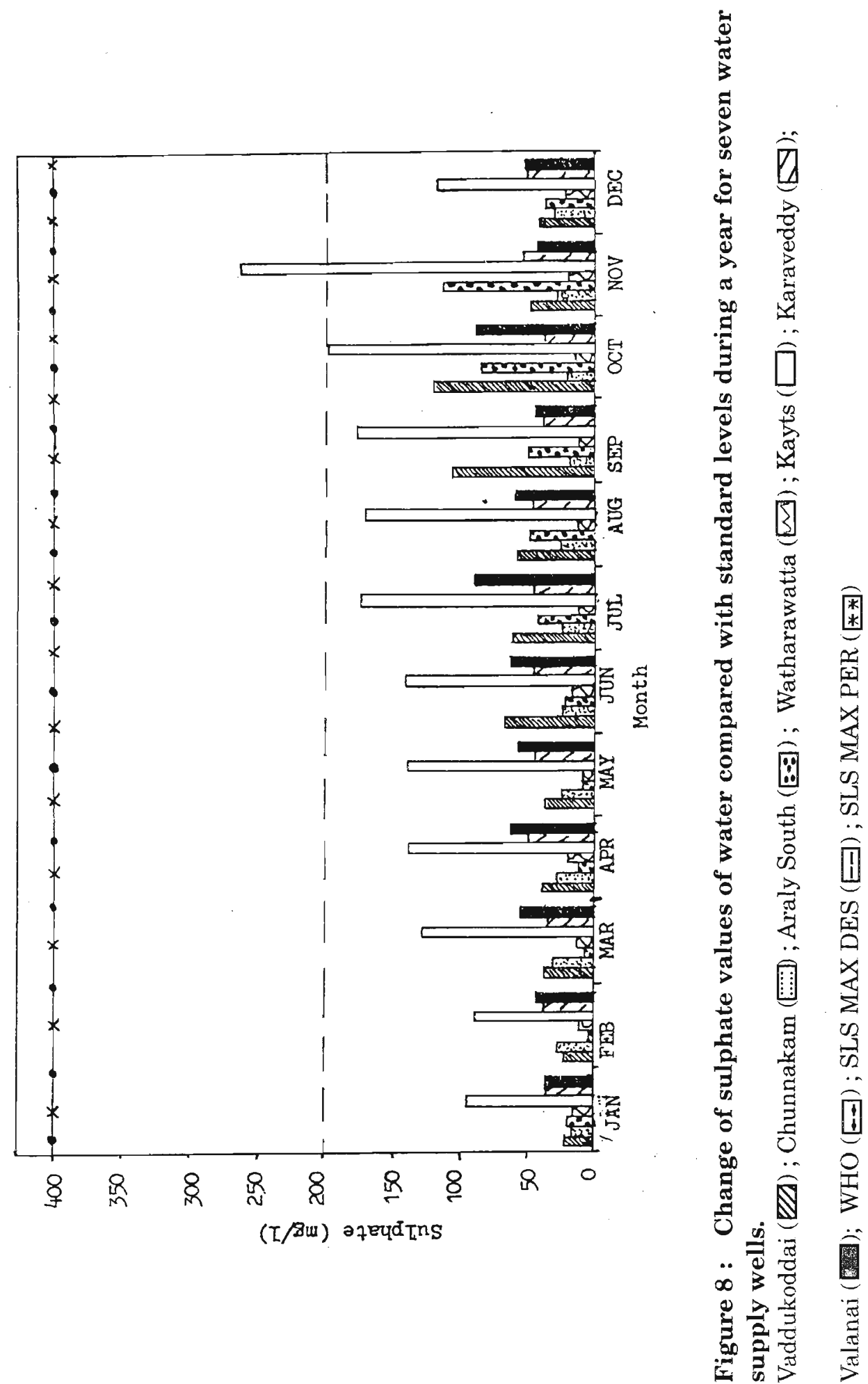
Araly South, Vaddukkodai and Watharawatta water supply wells can be used for pumping at present but total alkalinity (Figure 5), total dissolved solids (Figure 4), chloride (Figure 3), Iron (Figure 7), $\mathrm{pH}$ (Table 4), and electrical conductivity (Figure 6) values should be monitored continuously since these values deviate from standard levels in some months. Spray of sea water as droplets or crystals does increase chloride levels in the ground water in coastal areas. ${ }^{13}$ In places close to the sea such as Vaddukkoddai East and Araly North, where the water has a high electrical conductivity, salinity was reported to be high. ${ }^{14}$ These findings also support the results and confirm the possibility of increasing salinity in Araly South, Vaddukkodai and Watharawatta. Hence these wells have to be monitored continuously.

Most of the water supply wells had the peak total alkalinity values during the dry season, which may be due to high evaporation. As a result, the concentration of carbonates, bicarbonates and hydroxides would increase above the standard level. In view of the fact that the aquifer is mainly made up of limestone, covered by a thin mantle of highly permeable calcic latosols ${ }^{4}$, rapid movement of any ions not utilized by crops can reach the aquifers resulting in high ion levels. When rain water seeps through the soil salts such as calcium carbonate and calcium sulphate dissolve in it and finally end up with high concentration of dissolve solids during rainy season.

Compared with the other five water supply wells, water supply wells at Velani and Chunnakam did not have quality problems and can be used continuously for human consumption with monitoring. Although the aquifer of Chunnakam is highly exploited for drinking water and is located in an intensive agricultural area, the quality of water is not affected. According to the results of the aquifer characteristic test of Chunnakam limestone formation, the apparent transmissivity is $3700 \mathrm{~m}^{2} / \mathrm{d}$ while the hydraulic conductivity is $200 \mathrm{~m} / \mathrm{d} .{ }^{15}$ The high permeability of the aquifer results in relatively rapid recharge to the pumping well. Also the estimated quantity of the fresh water above the transition zone is 212 million $\mathrm{m}^{3} .^{15}$ This volume of groundwater is the largest and most heavily developed water source. The groundwater of the Jaffna peninsula has the highest nitrate content in Sri Lanka. ${ }^{16}$. However it could not be measured since essential chemicals for the analysis were not available in Jaffna. Rainfall data are also lacking to make possible correlations between ion concentrations and rainfall.

\section{CONCLUSION}

Among the selected seven water supply wells, Karaveddy and Kayts wells are to be suspended from further extraction of water. Hence new wells should be selected with required capacity and good quality to substitute for these wells for pumping water. The other five water supply wells could be used continuously under periodical monitoring of quality parameters. 


\section{Acknowledgment}

The authors wish to thank the Manager and Chemist of the National Water Supply and Drainage Board, Jaffna for providing facilities to analyze water samples and for their extended support throughout the study.

\section{References}

1 Balendran V. S., Srimanne C.H.L. \& Arumugam S. (1968). Ground water in Jaffna. Water Resources Board, Colombo. pp.1-16

2 Nandakumar V. (1983). Natural environment and ground water in the Jaffna peninsula, Sri Lanka. Climatological notes, Tsukuba, Japan. 33:155-164

3 Mageswaran R. \& Mahalingam S. (1983). Nitrate Nitrogen content of well water and soil from selected areas in the Jaffna peninsula. Journal of the National Science Council of Sri Lanka.11(1):269-275.

4 Nagarajah S., Emerson B.N., Abeykoon V. \& Yogalingam S. (1988). Water quality of some wells in Jaffna and Kilinochchi with special reference to Nitrate pollution. Tropical Agriculture. 44: 61 - 73.

$5 \quad$ Navaratnarajah V. (1994). Water problems in the Jaffna peninsula. Affordable water supply and sanitation, $20^{\text {th }}$ WEDC conference publication. pp,191-193.

$6 \quad$ World Health Organization (1984). Guidelines for drinking water quality Vol.1 :Recommendations. Geneva. 79pp.

$7 \quad$ Sri Lankan standard 614: part 1(1983). Specification for potable water physical and chemical requirements. pp. 5-10.

8 Subashchandra B. \& Selvakumari G. (1987). Principles of analytical chemistry. Department of soil science and agricultural chemistry, Tamil Nadu Agricultural University, Coimbatore. 34pp.

9 Wilcox L.V. \& Durum W.B. (1967). Quality of irrigation water. In: Irrigation of agricultural lands. (Eds. R.M.Hagan, H.R.Haise \&T.W.Haise). pp.104-107. American Society of Agronomy, USA.

10 Philippine Council for Agriculture and Resources Research, Republic of the Philippines. (1980). Standard methods of analysis for soil, plant tissue, water and fertilizer. Farm resources and systems research division, Laguna.pp.120123. 
11 Chresh Beale \& Sucking (1964). The examination of waters and water supplies. Cambridge University Press, Cambridge. pp. 198-241.

12 David Keith Todd (1995). Ground water hydrology. John Willey and sons. New York. pp.280-281.

13 Rajasooriya L.D.(1999). Geology and the groundwater resources of the Valigamam region in the Jaffna peninsula with special reference to water quality. M. Phil thesis. University of Jaffna, Sri Lanka. pp.12-13.

14 Puvaneswaran P. (1987). Geomorphology of the Valukkai Aru drainage basin. Sri Lankan Journal of South Asian Studies.1:43 - 58.

15 Democratic Socialist Republic of Sri Lanka and National Water Supply and Drainage Board (1984). Market town water supply - Jaffna Project, Master plan report, Engineering Science, Colombo.

16 Natural Resources of Sri Lanka. Condition and Trends. (1991). A report prepared for the Natural Resources, Energy and Science Authority of Sri Lanka. pp. 173 